\title{
MORFOLOGIA DO CLORETO DE COBRE NA PRESENÇA DE EXTRATOS AQUOSOS DE FEIJOEIRO (Phaseolus vulgaris $\quad$ L.) *
}

\author{
IBRAHIM OCTAVIO AbrahÃo **
}

\begin{abstract}
Apresenta-se o conjunto dos caracteres morfológicos observados em modēos de cristalização de orgãos de três variedades de feijoeiro (raiz, caule, folha, flor, semente) na aplicação do método de Pfeiffer. Alguns têrmos novos usados na descrição dos modelos são apresentados. Observouse grande variação na morfologia do cloreto de cobre na presença de extratos aquosos dos orgãos, o que possibilita distinção entre orgãos e entre variedades.
\end{abstract}

\section{INTRODUÇÃO}

O cloreto de cobre é o mais versátil de todos os sais na sua maneira de cristalizar a partir de soluções aquosas. Seu hábito de cristalização é modificado de maneira específica por substancias presentes na solução (companheiro de solução) e pode ser reproduzido sempre que se reproduzirem as mesmas condições. O método de Pfeiffer consiste na aplicação dessa versatilidade na caracterização de soluções.

A pesquisa com o método de Pfeiffer baseia-se, essencialmente, na observação, descrição e comparação de modelos de cristalização. Como os caracteres morfológicos variam grandemente, é necessário a sistematização das descrições, o que se consegue mediante uma terminologia própria das configurações que os cristais de cloreto de cobre podem assumir. A maior parte dos caracteres morfológicos que podem ocorrer é exaustivamente estudada por SELAWRY e SELAWRY (1957), na medida em que possam ter significado na distinção entre dois modelos de cristalização. $O$ presente trabalho apresenta os caracteres morfológicos observados em pesquisa sobre a aplicação do método de Pfeiffer a diferentes órgãos, de diferentes variedades de feijoeiro (Phaseolus vulgaris L.).

* Entregue à publicação em 7-12-1971.

** Departamento de Solos e Geologia, ESALQ - USP. 


\section{REVISÃO DA LITERATURA}

Desde que PFEIFFER (1930) pela primeira vez utilizou a cristalização do cloreto de cobre como um método de estudo de soluções, numerosos trabalhos tem sido publicados sobre a aplicação do método, principalmente na Alemanha. $\mathrm{Na}$ sua maior parte, tratam da diagnose de moléstias por essa via, utilizando principalmente sangue como companheiro de solução. Aplicações do método a plantas são em menor número e referem-se, geralmente, a espécies de interesse medicinal, mas, pelo que apresentam de geral para plantas, despertam interesse. PFEIFFER (1930), em seu trabalho original, aplicou o método a plantas, assinalando diferenças nos modelos de cristalização causadas por adubação. PFEIFFER (1940), trabalhando com plantas sãs e atacadas por fungos, observou diferenças significativas nos modelos de cristalização, relacionadas ao número de centros de cristalização e ao comprimento das agulhas. MORRIS E MORRIS (1938) aplicaram o método de Pfeiffer a extratos de aveia, trigo e milho, observando que os modelos para cada tipo de semente são sempre característicos. Pesquisaram, também, a perda de atividades dos extratos, constatando que a atividade diminui em 24 horas, à temperatura ambiente, ou em 10 minutos, se o extrato é aquecido a $100^{\circ} \mathrm{C}$. MORRIS E MORRIS (1939) trabalharam com extrato de milho doce, comparando o modelo obtido com o do polissacarídeo correspondente, prèviamente isolado. MORRIS E MORRIS (1941) determinaram que pequenas quantidades de proteinas podem afetar sensìvelmente os modelos obtidos com polissacarídeos. KRÜGER (1949) estudou, em extratos de Hyosciamus niger, a influência da hora de coleta do material sobre os modelos de cristalização, observando aue o modelo decresce em nitidez conforme a coleta se faça de manhã, à tarde ou à noite, KRÜGER (195U) aplicou o método a diferentes orgãos de diferentes espécies vegetais, a maior parte das quais de caráter medicinal, procurando estabelecer correlação entre o modelo obtido com a planta e o referente ao orgão para o qual a planta é medicinal. SELAWRY E SELAWRY (1957) estudam pormenorizadamente a cristalização do cloreto de cobre, examinando todos os aspectos do método e as influências que exercem os mais variados fatores, como temperatura, umidade relativa, taxa de evaporação, concentração, lavagem das placas e outros. Estudam os modelos obtidos com substâncias puras, extratos de plantas, de tecidos animais e, principalmente, com sangue. Estudam de maneira sistemática e minuciosa os caracteres morfológicos que devem ser considerados nos modelos de cristalização. A maior parte de seus resultados refere-se à diagnose de moléstias. O capítulo referente a plantas é menos pormenorizado, assinalando-se, todavia, que os modelos de cristalização permitem a distinção de ervilhas obtidas de solos arenosos ou argilosos, adubadas mineral ou orgânicamente. ABRAHÃO 
(1965) aplicou o método de Pfeiffer a extratos aquosos de diferentes orgãos, de diferentes variedades de feijoeiro, em diferentes estágios de desenvolvimento, obtendo o material a partir de soluções nutritivas completas. O estudo morfológico dos modelos obtidos conduziu à maior parte dos resultados apresentados no presente trabalho. $\mathrm{O}$ autor assinala as diferenças morfológicas que permitem a diferenciação de variedades de orgãos e de estágios de desenvolvimento. ABRAHÃO (1970) aplicou o método de Pfeiffer a sementes de café com ${ }^{\circ}$ objetivo de estabelecer as melhores concentrações de cloreto de cobre e de extrato para pesquisas com esse material, recomendando que deve ser empregada a técnica de mistura filtrada e concentrações entre 0,05 e 0,075g de extrato por placa e entre 0,5 e 1,0g por placa de cloreto de cobre.

\section{MATERIAIS E MÉTODOS}

\section{MATERIAIS}

\subsubsection{Variedades}

Utilizaram-se tres variedades de feijoeiro (Phaseolus vulgaris L.) : roxinho, pintado e preto

\section{Câmara de cristalização (fig. 1)}

Os modelos de cristalização foram obtidos em câmara de cristalização especial (fig. 1), construída segundo recomendações de SELAWRY E SELAWRY (1957). Tem dimensões de 1,60m x 1,60m x $2.00 \mathrm{~m}$, paredes duplas, adiabáticas, laváveis do lado interno. $\mathrm{O}$ aquecimento se obtem por irradiação de resistência de 36, 72 e 145 ohm, localizadas na base da câmara. Dispõe de uma mesa de vidro, suspensa do teto, de $0,70 \mathrm{~m} \times 1,50 \mathrm{~m} \times 0,001 \mathrm{~m}$, regulável em altura e perfeitamente nivelada. Acima da mesa e sobre seu centro está o bulbo de um termoregulador de contacto automático, que permite o controle de temperaturas até $50^{\circ} \mathrm{C}$, com precisão de $0,1^{\circ} \mathrm{C}$. A câmara é provida de iluminação interna, dois respiros, um visor na porta e um ventilador com duas velocidades e localiza-se em ambiente asséptico.

\section{Placas de cristalização}

Säo placas especialmente montadas, constituídas de um vidro circular plano sobre o qual coloca-se um anel de vidro de $9 \mathrm{~cm}$ de diâmetro interno e de $1 \mathrm{~cm}$ de altura. A colagem foi feita com araldite, obtendo-se uma montagem definitiva.

\section{cloreto de cobre e material fotográfico}

Usou-se cloreto de cobre puríssimo p.a. Merck. Para fotografia, os melhores resultados foram alcançados com filmes de $35 \mathrm{~mm}$ Panatomic-x e papel Kodabromide $F-4$, pois ambos permitem grandes ampliações 


\section{MÉTODOS}

\section{Coleta do material e obtenção do extrato}

As plantas foram obtidas a partir de soluções nutritivas completas e coletadas às $8,00 \mathrm{~h}$, segundo recomendações de KRÜGER (1949) e cuidadosamente lavadas. Os diferentes orgãos foram separados, pesados, triturados em gral de vidro, adicionando-se, então, água bidestilada na proporção de 1:9 e filtrandose, em papel Whatman n. ${ }^{\circ}$ 1. O extrato assim obtido é diluído posteriormente nas concentrações desejadas, de maneira que se possa pipetar em $3 \mathrm{~m} 1$ a quantidade desejada por placa. Os $3 \mathrm{~m} 1$ são levados a um tubo de ensaio juntamente com $3 \mathrm{~m} 1$ da solução de cloreto de cobre, contendo a quantidade desejada do sal por placa.

\section{Limpeza das placas de cristalização}

As placas são lavadas com água quente e, em seguida, com soda morna a 5\%. Lavadas novamente com água corrente, recebem depois, sucessivamente, soluções de $\mathrm{HC1}$ a $3 \%$ (10 minutos), $\mathrm{NaF}$ a $2 \%$ (10 minutos) e $\mathrm{H}_{2} \mathrm{SO}_{4}$ a $3 \%$ (10 minutos). Em seguida, são lavadas repetidas vezes com água destilada e bidestilada. São, então, secas ao ar, numeradas e levadas à mesa de vidro da camara de cristalização.

\section{Decurso da cristalização}

A solução conjunta de extrato e cloreto de cobre é transferida para as placas de cristalização, com a camara já na temperatura desejada $\left(30^{\circ} \mathrm{C}\right)$. As placas são dispostas em posição casualizada, de maneira que as repetições (geralmente 5) de um série não fiquem do mesmo lado da mesa de vidro. Decorridas 10 - 12 horas, a água terá sido evaporada e nas placas estarão os cristais de cloreto de cobre dispostos segundo um determinado modelo. O controle de umidade relativa pode ser feito com bandejas contendo silica-gel em quantidade proporcional ao número de placas.

\section{Exame, descrição e protocolo das placas}

O exame das placas é feito por séries, isto é, pelo conjunto das placas que receberam o mesmo material, descartando-se as eventuais repetições discrepantes. As placas são descritas, protocoladas e fotografadas individualmente, obtendo-se uma fotografia da placa inteira e outras regiões de maior interesse. A descrição individual se faz através dos caracteres morfológicos presentes, chegando-se a uma descrição que representa toda a série. 


\section{RESULTADOS}

Apresentam-se, a seguir, os principais caracteres morfológicos observados na cristalização do cloreto de cobre, tendo extratos aquosos de feijoeiro como companheiros de solução. Adota-se a nomeclatura de SELAWRY E SELAWRY (1957), que já descreveram a maior parte desses caracteres. Observaram-se, entretanto, alguns caracteres não descritos por aqueles autores, introduzindo-se, então, termos novos, indicados por (*). Para todos os caracteres podem ocorrer tipos de transição, o que é esperado para um critério descritivo meramente qualitativo. O autor considera, em consequência, ser desejável uma quantificação dos caracteres, o que conduziria a uma maior consistência estatística dos resultados.

Os caracteres morfológicos dos modelos de cristalização podem ser divididos em duas categorias: gerais, referentes a uma visão de conjunto do modelo, podendo, pois, ser descritos para qualquer modelo, e particulares, representados por pormenores ou partes de um modelo de cristalização, podendo ocorrer em um modelo e estar ausentes em outro. Tanto os caracteres gerais com os particulares podem ser diferenciais de modelos, o que efetivamente se observou para feijoeiro.

Ilustram-se os caracteres descritos com fotografias de placa inteira ou de regiões, com o respectivo aumento, indicando-se também o orgão, a variedade e a concentração com que foi observado o caráter morfológico, podendo uma mesma fotografia ilustrar mais de um caráter.

\section{Caracteres gerais}

\section{Cor}

A cor da solução aquosa de cloreto de cobre varia, em função da concentração, de azul a verde. Observou-se, entretanto, que o companheiro de solução pode afetar a cor da cristalização, mesmo a partir de concentrações iguais do sal. Para raízes, por exemplo, é frequente uma tonalidade de verde mais clara do que para folhas.

\section{Deferenciação geral *}

A diferenciação geral de um modelo pode ser afetada pelo companheiro de solução, por concentração excessiva ou insuficiente de cloreto de cobre ou por fatores ligados ao processo de cristalização: temperatura, umidade relativa, taxa de evaporação. Estes últimos mantidos constantes, observaram-se efeitos de concentração e companheiro de solução. Diferenciação geral incipiente foi observada por insuficiência de extrato, obtendo-se modelos semelhantes para soluções diferentes (fig. 2). Para concentrações identicas, obteve-se boa 
diferenciação geral em alguns casos, com diferentes extratos (figs. $3,4,5)$. O efeito de excesso de concentração sobre a diferenciação geral pode ser observado para extrato de flores (figs. 4 e 6). Companheiro de solução provocando má diferenciação geral foi muito frequente para extratos de raízes e flores (fig. 7).

\section{Centragem}

Observaram-se modelos de cristalização com vários graus de centragem. Frequentemente para sementes ocorreu centragem perfeita, com toda a cristalização filiada a um centro puntiforme (fig. 3) ou representado por uma área de cristalização restrita (fig. 8). Casos de centragem má foram observados na ausência de centros de cristalização nítidos (fig. 2). ou quando não se pode filiar cada parte da cristalização a um centro (fig. 7). Casos intermediários são frequentes, com dois ou mais centros nítidos, cada um relacionado a determinada área do modelo de cristalização (fig. 9).

\section{Coordenação}

Observaram-se modelos de coordenação perfeita, em que o crescimento dos cristais se faz segundo a mesma orientação geral, sem perturbação de centros secundários ou outros elementos (fig. 5). Frequentemente, a coordenação é comprometida por cristalização fibrosa (figs. 6 e 7), não se podendo estabelecer uma orientação geral definida para os cristais. A coordenação perfeita pode ser prejudicada por centros de cristalização secundários (fig. 9).

\section{Irradiação}

A maneira como as agulhas de cloreto de cobre se desenvolveram dos centros para as bordas é variável. Não se observaram, para feijoeiro, casos de configuração radial, em que as agulhas se desenvolvem bem individualizadas dos centros para as bordas. Exemplos de irradiação boa. embora não perfeita. são frequentes figs. 5 e 10), ocorrendo também casos em que as agulhas não tem uma direção predominante (fig. 6) ou desviam-se como se fossem curvas (fig. 11).

\section{Cobertura}

Embora seja um caráter dependente, em primeiro lugar, da concentração de cloreto de cobre, observaram-se diferenças nítidas de cobertura para a mesma concentração, em função do companheiro de solução. Modelos de cristalização de grande cobertura foram observados, nos quais nenhuma parte da superfície da placa é observada sem cristais (fig. 12). Em outros casos, a cobertura é parcial, em função da individualidade das agulhas, do seu espaçamento, da presenca de formas vazias ou de espaços irregulares (fig. 26). De um modo geral, a cobertura é diferente na cristalização central e na periferia (fig. 5 ). 


\section{Caracteres particulares}

\section{Centro de cristalização}

Observou-se variação nos centros de cristalização com relação ao seu número, posição e tipo. Alguns modelos exibem centros perfeitamente puntiformes (figs. 13 e 14), outros apresentam centros difusos (fig. 15), outros não são puntiformes, mas representados por uma área muito restrita, á qual se filia a cristalização (fig. 8). Com relação ao número, observaram-se modelos de apenas um centro (fig. 3) ou de mais de um centro (figs. 9 e 16).

\section{Individualidade}

Em princípio, a cristalização do cloreto de cobre, nas condições descritas, é acicular. O desenvolvimento dos cristais, entretanto, pode conduzir ou não a modelos em que as agulhas podem ser observadas individualmente. Observaram-se desde modelos com cristais bem individualizados, longos e de bom calibre (fig. 17 e 18), até modelos em que, por excessiva ramificação ou por seu pequeno comprimento e calibre, as agulhas não podem ser observadas isoladamente (figs. 6, 7. e 12). De uma maneira geral, modelos com cristalizacão fibrosa e com espessamentos são os de menor individualidade.

\section{Cristalização fibrosa *}

Observou-se, com muita frequência, um tipo de cristalização de diferenciação geral, coordenação e irradiação muito más, em que os cristais tem um mínimo de individualidade (fig. 6 e 7). As agulhas de cloreto de cobre são tão finas que o caráter passa a ser mais fibroso do que acicular. É um conjunto de cristais muito curtos e finos, de orientação heterogênea, cobrindo toda a placa ou localizado em áreas da cristalização, podendo mesmo ocorrer entre cristais de boa individualidade (fig. 19). Essa cristalização fibrosa geralmente se apresenta com tonalidade mais clara que o usual, sendo muito frequente em modelos de extratos de raízes.

\section{Espessamentos *}

Associados à cristalizacão fibrosa, ocorrem, algumas vezes, concentrações de cristais de clo sto de cobre em pontos da placa, sem qualquer individualidade dos c 1 istais, de côr mais clara que a predominante no modelo, com contorno irregular, espessas e, via de regra, mais altas que o restante da cristalização. Essas formações massivas foram denominadas espessamentos (fig. 20).

\section{Borda}

Não se observou nenhum caso em que os cristais de cloreto de cobre atingem o anel da placa de cristalização irradiando-se direta- 
mente a partir dos centros. Todos os modelos exibem borda, evidenciando com maior ou menor nitidez o limite da cristalização central. Observaram-se diferentes graus de diferenciação da borda, predominando, para folhas, bordas bem diferenciadas e, para raízes, mal diferenciadas. No primeiro caso, a borda resolve-se em pequenos feixes de cristais, bem caracterizados, observáveis com maior nitidez nas proximidades dos centros de cristalização, quando este não é central. Observou-se, também, o que se denominou borda vitrificada *, sem qualquer indício de diferenciação, com brilho vítreo, às vezes inteiramente homogênea (figs. 6, 7, 19 e 20), frequente em extratos de raízes. Os casos intermediários ocorrem.

\section{Ramificações}

Embora na cristalização do cloreto de cobre seja possível a ocorrência de agulhas individuais que vão do centro à periferia da placa, não é esse o caso para extratos de feijoeiro. Geralmente, logo após o centro, ramificam-se repetidamente, assumindo aspectos característiocs (figs. 14, 23 e 24). Essa ramificação pode ser muito fina, quando de uma agulha principal nascem outras de dimensões cada vez menores. O caso mais frequentemente constatado foi o da ramificação em leques.

\section{Leques}

É comum que uma agulha se ramifique de tal maneira, em um ponto, que resulta uma forma semelhante às hastes de um leque (fig. 25), que, por se localizarem na parte terminal da agulha, nunca ocorrem na cristalização central. Variam em função do seu ângulo, da sua simetria, de seu caráter simples ou duplo, podendo, mesmo, ocorrer com aspecto fibroso (fig. 26).

\section{Anéis concêntricos}

É muito frequente nos modelos bem diferenciados a ocorrência de uma série nítida de anéis concêntricos na borda (figs. 4, 10, 21, 22 e 23). Constituem o lugar geométrico de sucessivas ramificações em leques de agulhas da borda. São perfeitamente circulares se o centro de cristalização é central, cas, contrário as distâncias que guardam entre si são menores nas proximidades do centro de cristalização do que do lado oposto, onde diminui sua nitidez.

Às vezes, a borda contem linhas concentricas * extremamente finas, nas quais não se pode observar a diferenciação descrita para os anéis concêntricos (fig. 19). As linhas concêntricas são típicas de borda mal diferenciada e os anéis concêntricos ocorrem nas bordas bem diferenciadas. 


\section{Cristalização transversal}

Esse caráter, de muito significado na diagnose de moléstias pela cristalização do cloreto de cobre com soluções de sangue, foi observado em alguns casos em feijoeiro, especialmente em folhas. Trata-se de uma agulha de calibre maior que o das demais ou de um feixe de agulhas que se forma transversalmente à irradiação dominante, formando ou não com esta um ângulo de $90^{\circ}$ (figs. 4 e 27).

\section{Deposições}

Observou-se grande variação na ocorrência de deposições. Frequentemente, sua ocorrência está ligada à concentração da solução e grau de turbidez do extrato. Para feijoeiro, ocorrem em maior quantidade para folhas e sementes. Quando presentes em grande quantidade, podem prejudicar a nitidez dos modelos de cristalização. São muito frequentes entre agulhas (figss. 18 e 24 ), na borda ou no interior de formas vazias (figs. 28, 29 e 30). Podem variar quanto ao seu aspecto mais ou menos fino, chegando a mostrar diferenciação dentrítica (fig. 28) e podendo se constituir em caráter diferencial de uma série.

\section{Formas}

Os aspectos e desenhos formados por um conjunto de agulhas varia em função da sua localização na placa, das agulhas delimitantes, de espaços vazios formados por seu contorno e de eventuais deposições presentes. Observaram-se formas radiais, que nascem de um único centro de cristalização, formando estrelas, se desse centro irradiam agulhas isoladas (fig. 13) e rosetas, de vários tipos e de perfeição variável, se do centro nascem feixes de agulhas (fig. 31). Em outros casos, as agulhas delimitam formas vazias, que fecham um determinado contorno, muito variável em forma. As formas vazias são frequentemente poligonais (fig. 32 e 33), podendo-se aproximar de formas arredondadas em função do número de lados. Quanto a sua delimitação, observaram-se casos intermediários (figs. 25 e 31 ), desde formas vazias rudimentares (fig. 34) até as de delimitação perfeita (figs. 28, 32 e 33 ).

É comum a ocorrência de espaços vazios irregulares*, que são áreas de contorno irregular, parcial ou totalmente isentas de cristalização, de fácil reconhecimento (fig. 26).

Observam-se, ainda, tipos de transição muito variados, em que não se delimita uma forma vazia, obtendo-se tipos de U (fig. 25). 
figura 1: câmara de cristalização

figura 2: caule, variedade roxinho, $0,01: 0,1$, x 0,56

figura 3: semente, variedade preto, $0,05: 0,5, \mathrm{x} 0,56$

figura 4: flor, variedade roxinho, 0,05:0,5, x 0,56

figura 5: semente, variedade preto, $0,05: 0,5$, x 0,84

figura 6: flor, variedade roxinho, $0,05: 1,0$, x 0,56

figura 7 : flor, variedade roxinho, $0,01: 0,75, \times 0,56$

figura 8: semente, variedade roxinho, $0,025: 0,75$, x 4,6

figura 9: semente, variedade preto, $0,05: 0,5$, x 0,56

figura 10: caule, variedade pintado, $0,05: 0,5$, x 0,84

figura 11: folha, variedade pintado, $0,05: 0,5$, x 0,56

figura 12: raiz, variedade preto, $0,05: 0,75$, x 3,4

figura 13: flor, variedade roxinho, $0,025: 0,5$, x 4,6

figura 14: folha, variedade preto, $0,05: 0,5$, x 2,5

figura 15: raiz, variedade pintado, $0,05: 0,5$, x 2,5

figura 16: caule, variedade roxinho, $0,05: 0,5$, x 2,5

figura 17: semente, variedade roxinho, $0,025: 0,75$, x 2,9

figura 18: semente, variedade roxinho, $0,05: 0,5$, x 2,5

figura 19: raiz, variedade pintado, $0,05: 0,5$, x 2,5

figura 20: caule, variedade roxinho, $0,05: 0,75$, x 0,84

figura 21: folha, variedade preto, $0,05: 0,5, \times 2,5$

figura 22: folha, variedade roxinho, $0,05: 0,5, \times 2,5$

figura 23 : folha, variedade preto, $0,05: 0,5$, x 2,5

figura 24: semente, variedade roxinho, $0,05: 0,5, \times 2,9$

figura 25: caule, variedade roxinho, $0,05: 0,5$, x 2,5

figura 26: raiz, variedade roxinho, $0,05: 0,05, \times 2,5$

figura 27: flor, variedade roxinho, $0,05: 0,5$, x 2,5

figura 28: semente, variedade roxinho, $0,025: 0,75$, x 5,0

figura 29: semente, variedade roxinho, $0,025: 0,5$, x 2,9

figura 30: semente, variedade roxinho, $0,05: 0,05, \mathrm{x} 2,5$

figura 31: caule, variedade roxinho, 0,05:0,5, x 3,8

figura 32: semente, variedade roxinho, $0,025: 0,75$, x 5,9

figura 33: semente, variedade roxinho, $0,025: 0,75$, x 5,5

figura 34: caule, variedade pintado, 0,05:0,75, x 4,2 


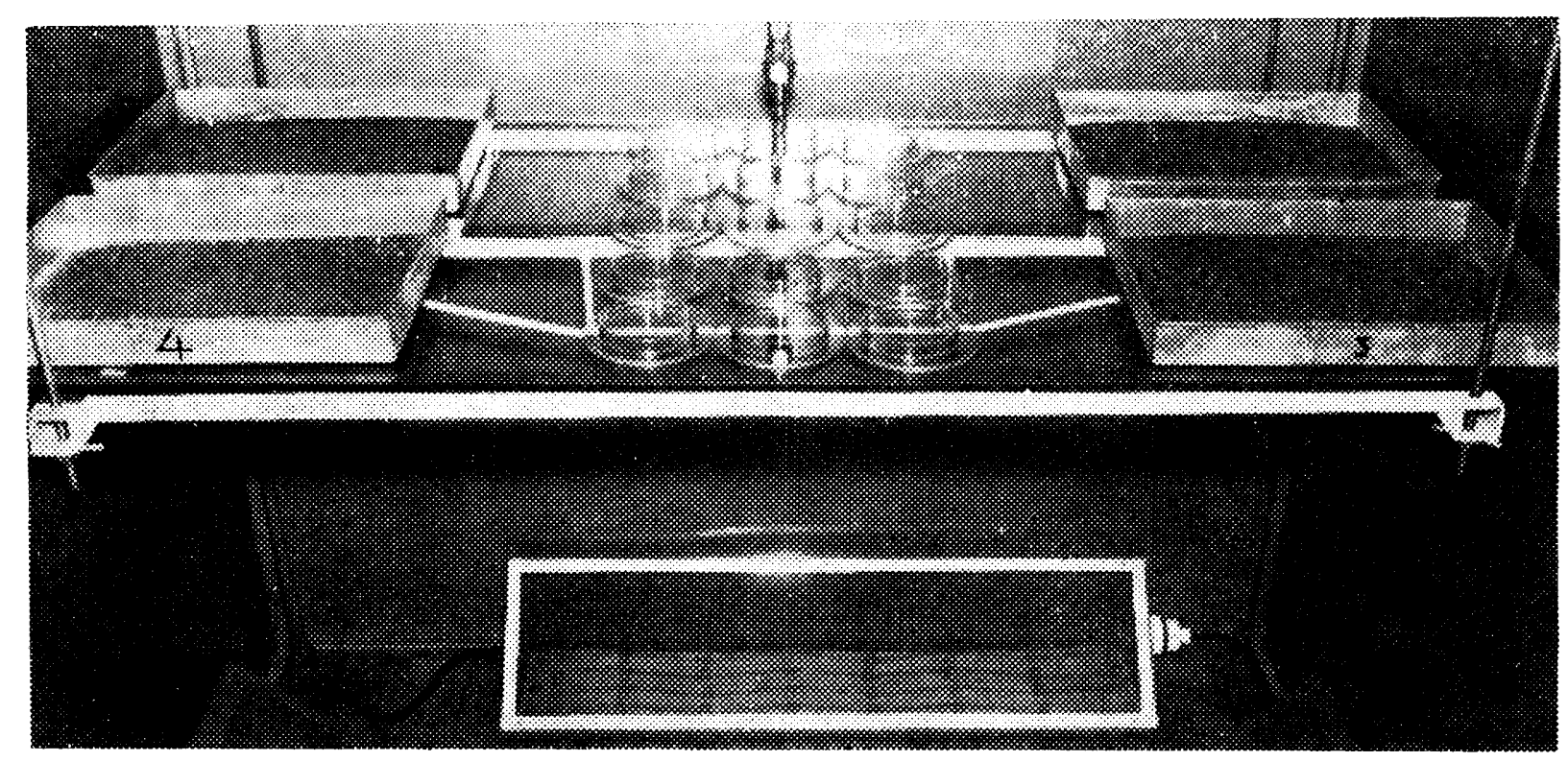

fig. 1

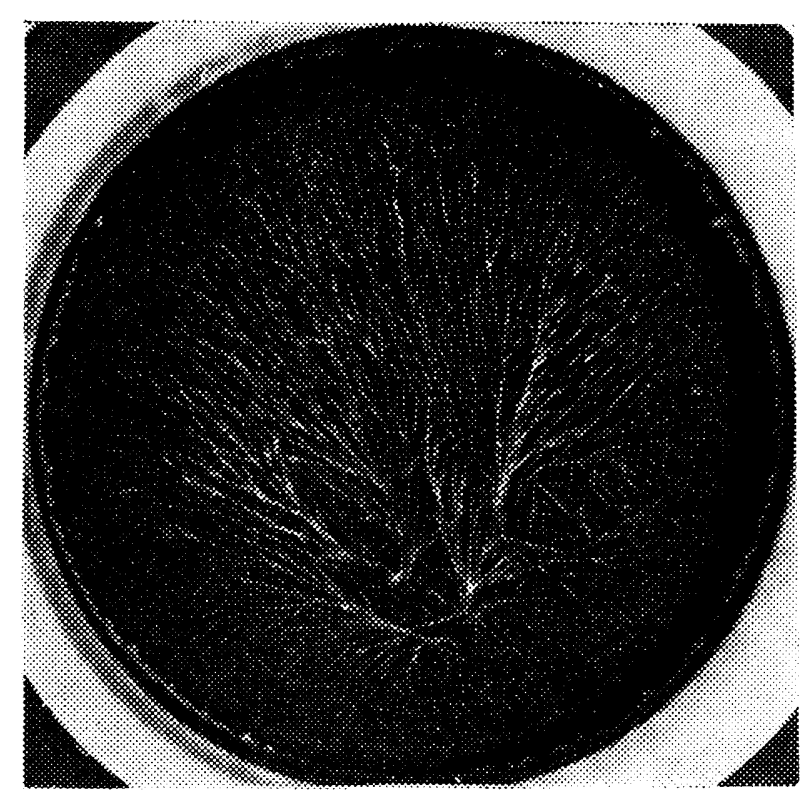

fig. 2

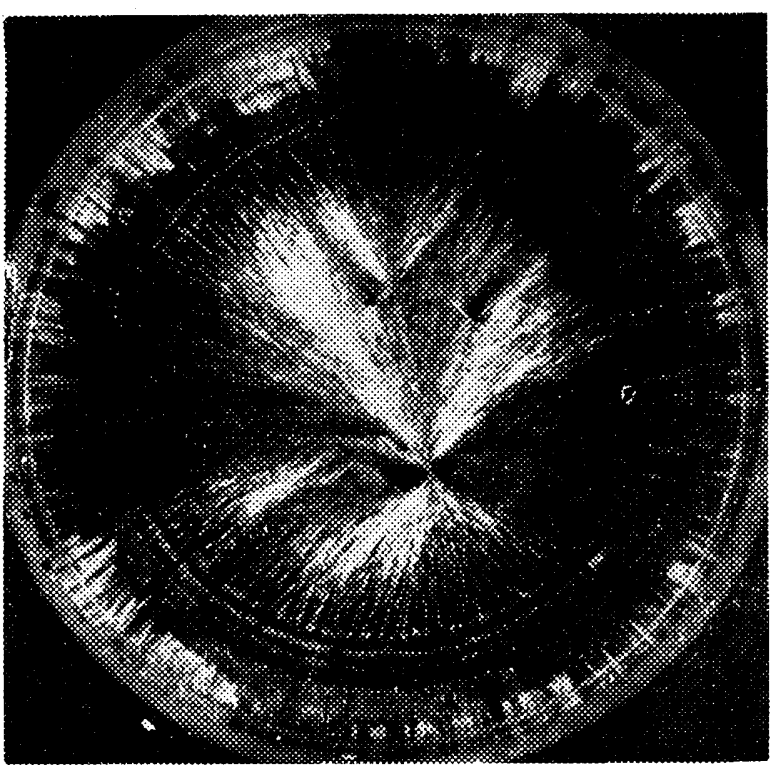

fig. 4

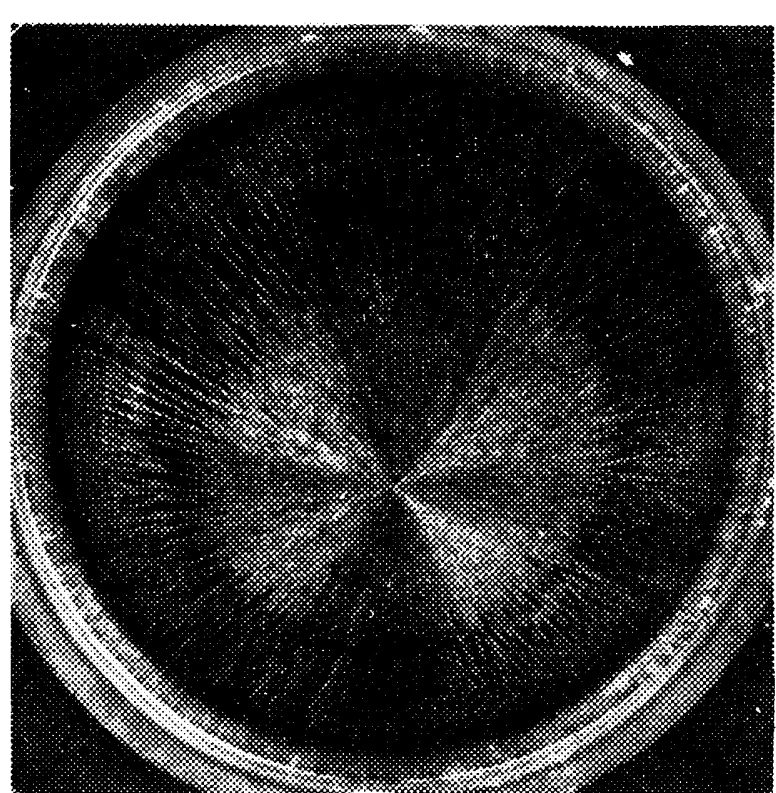

fig. 3

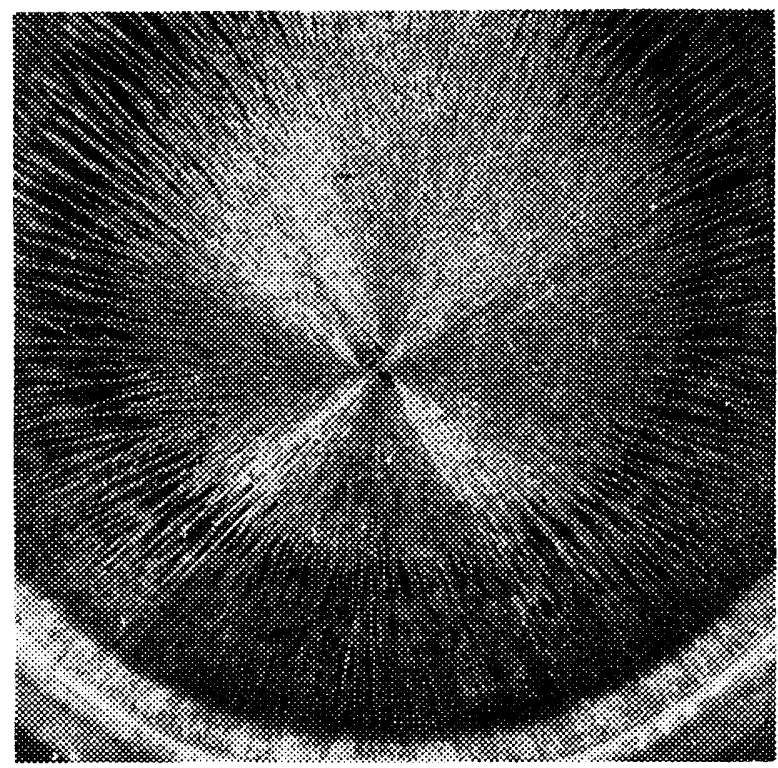

fig. 5 


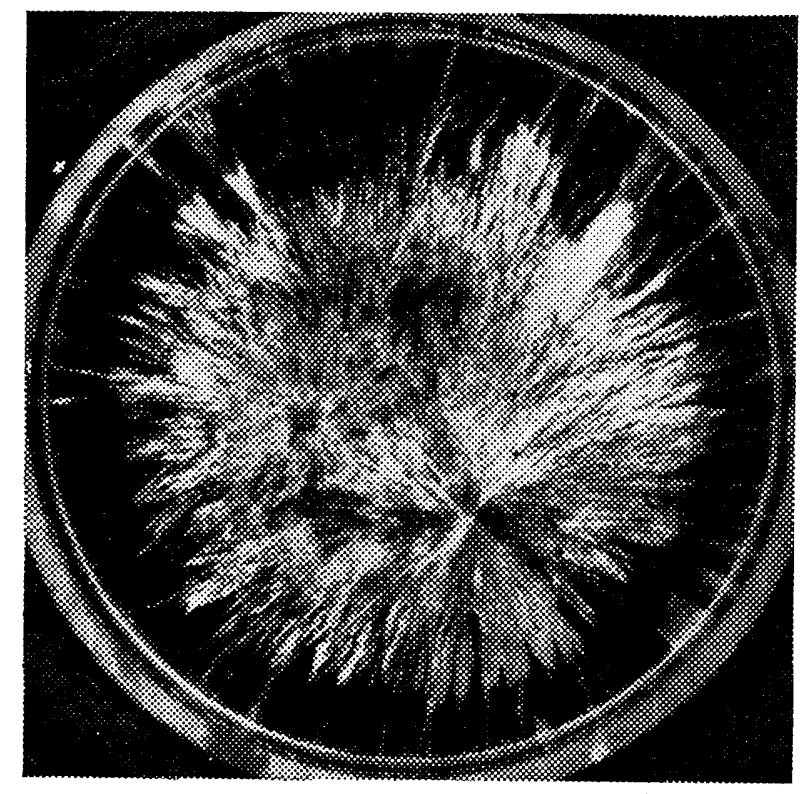

fig. 6

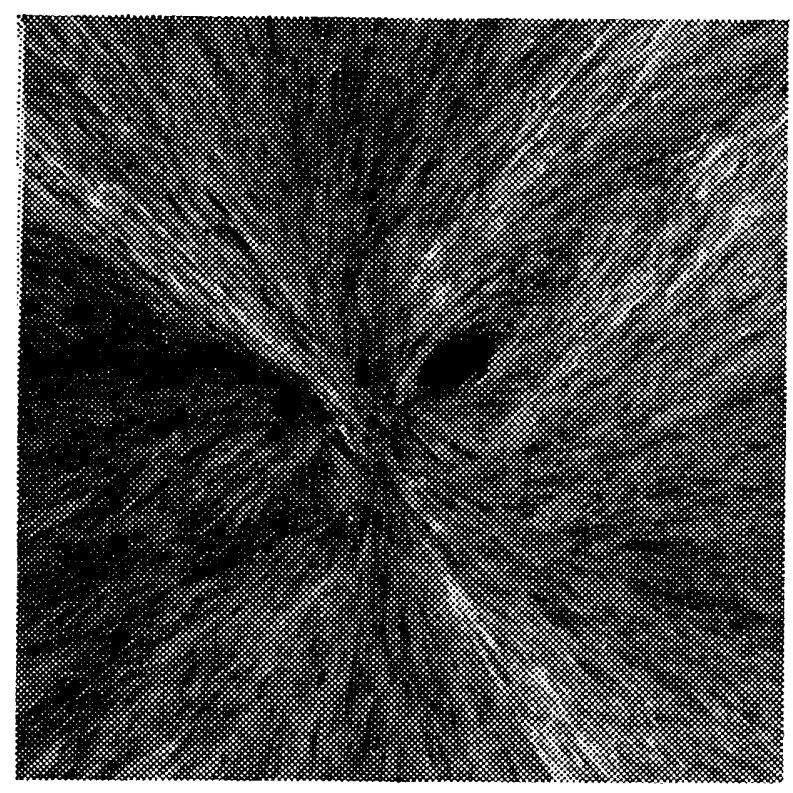

fig. 8

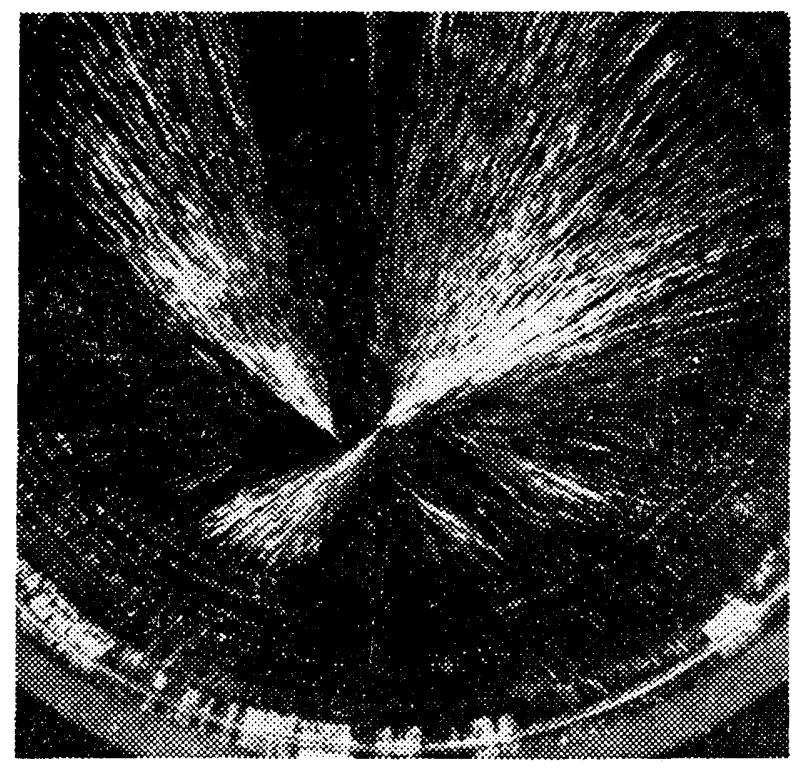

fig. 10

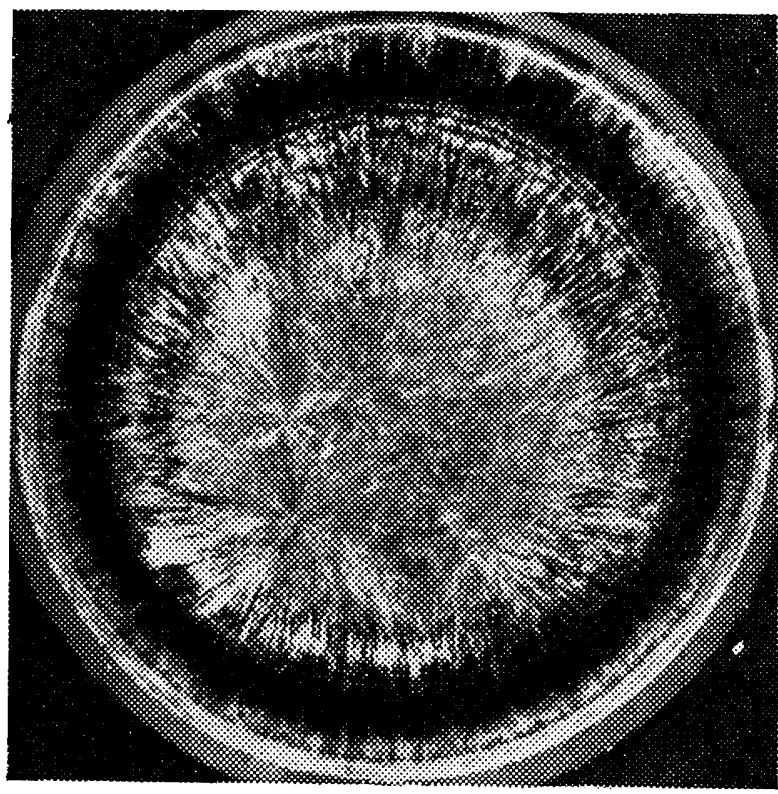

fig. 7

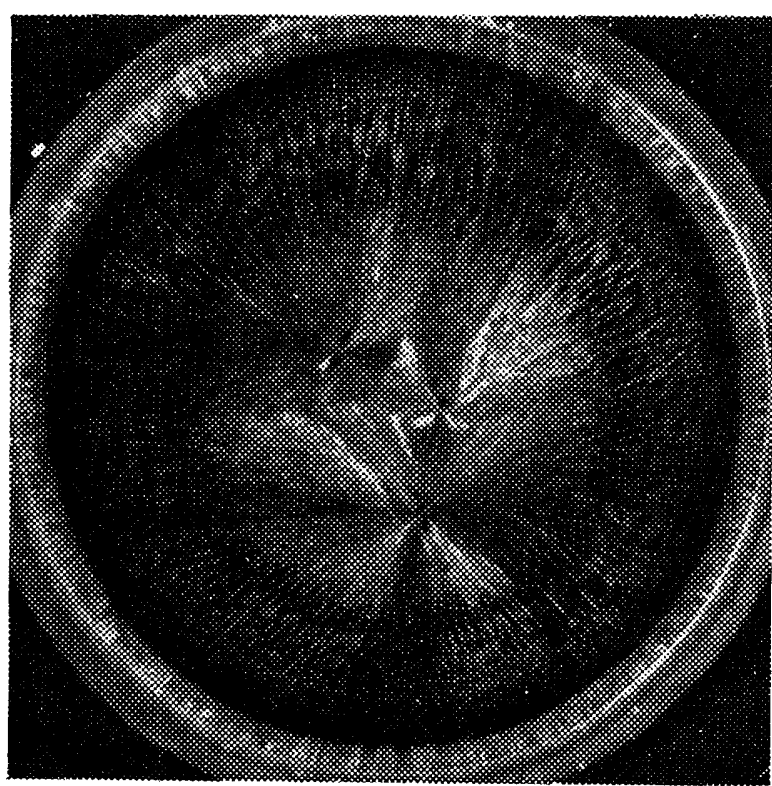

fig. 9

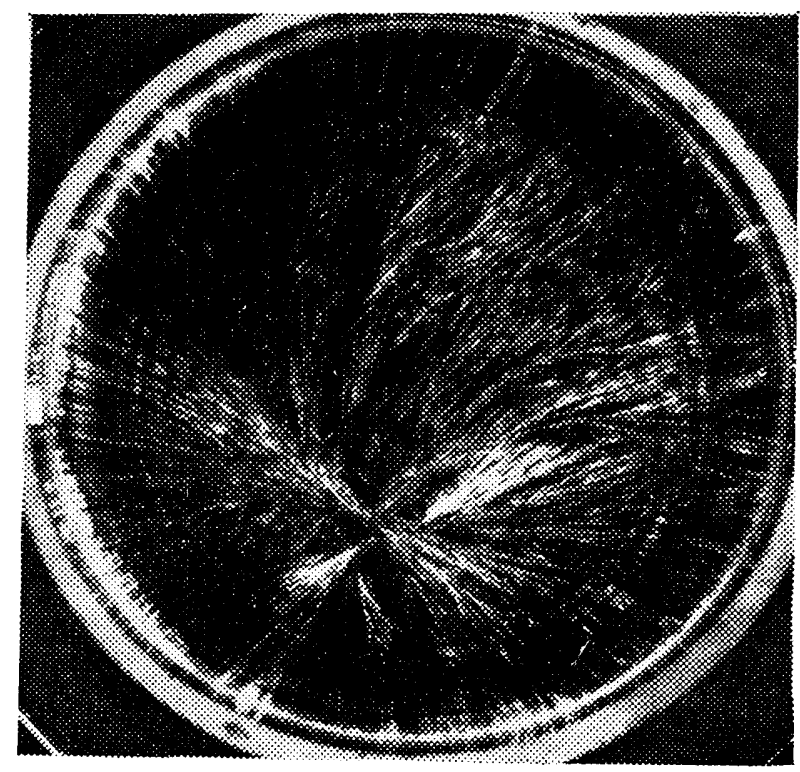

fig. 11 


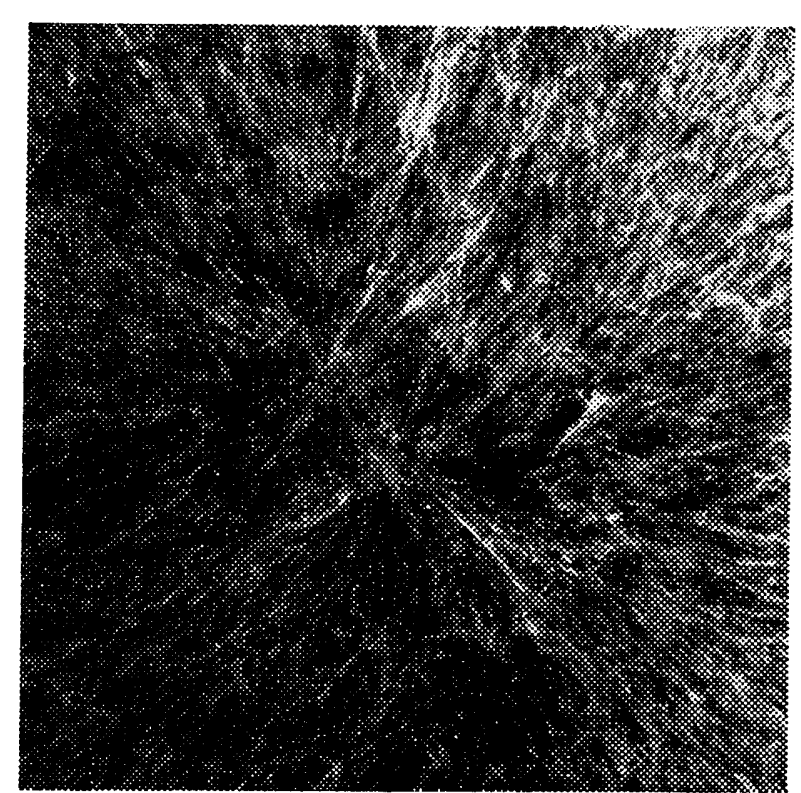

fig. 12

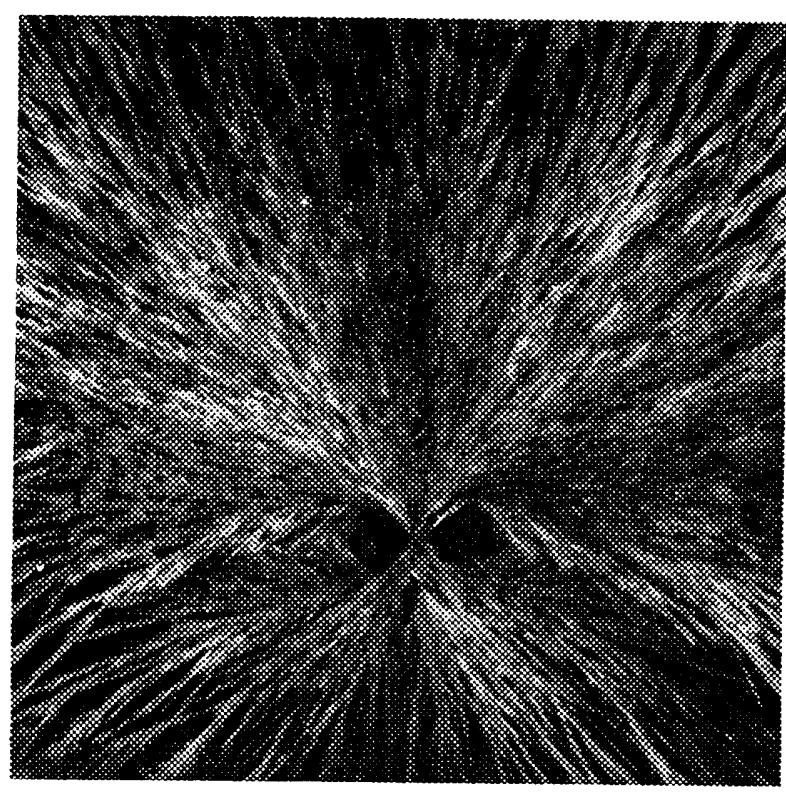

fig. 14

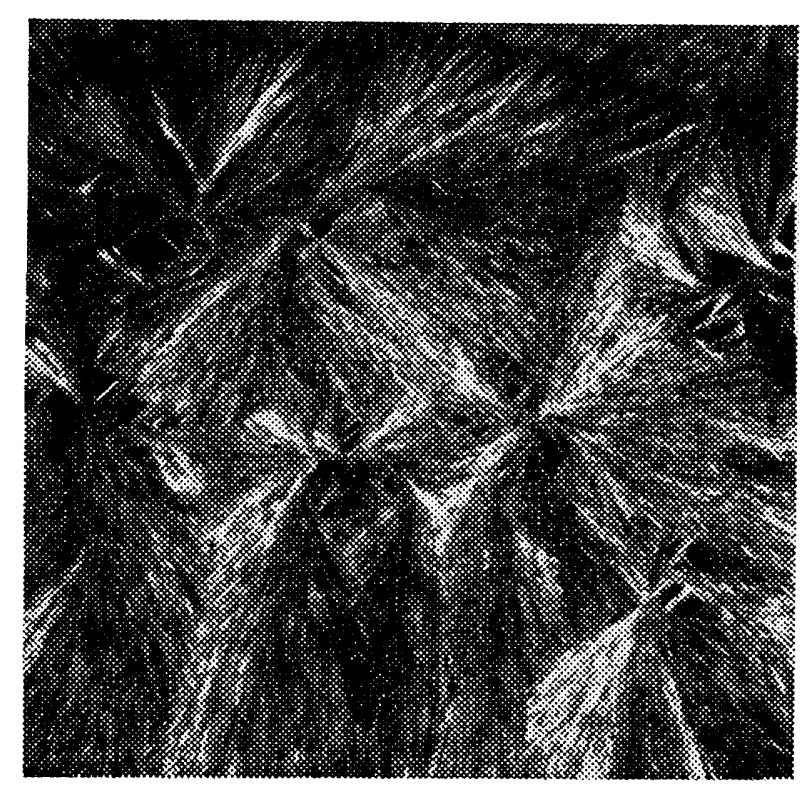

fig. 16

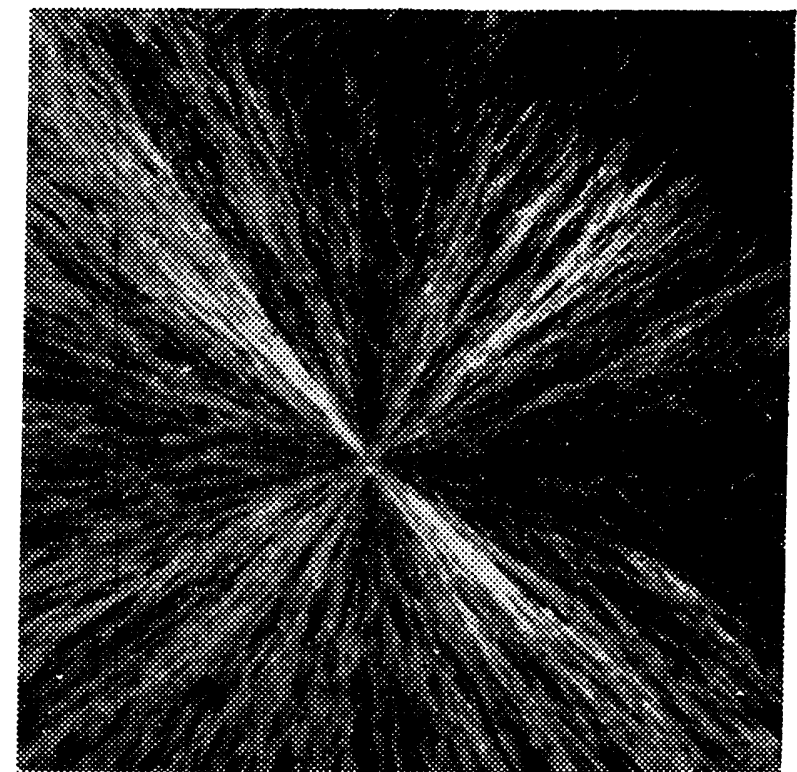

fig. 13

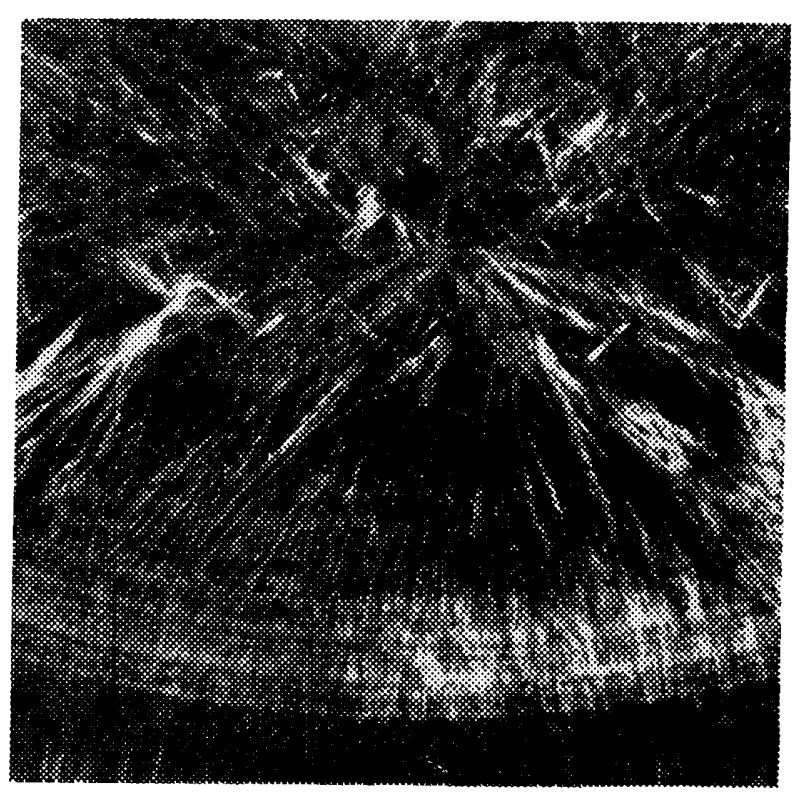

\section{15}

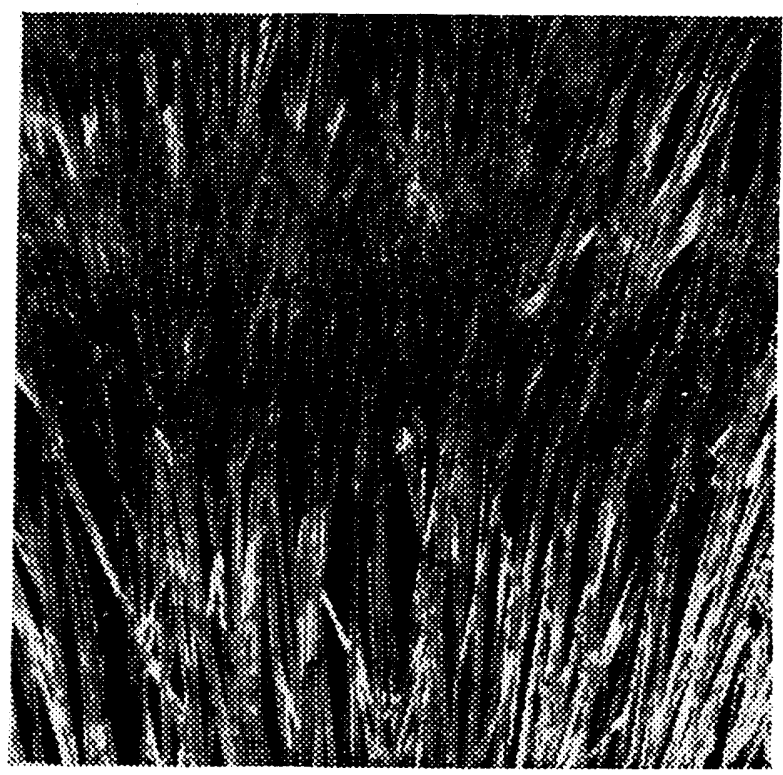

fig. 17 


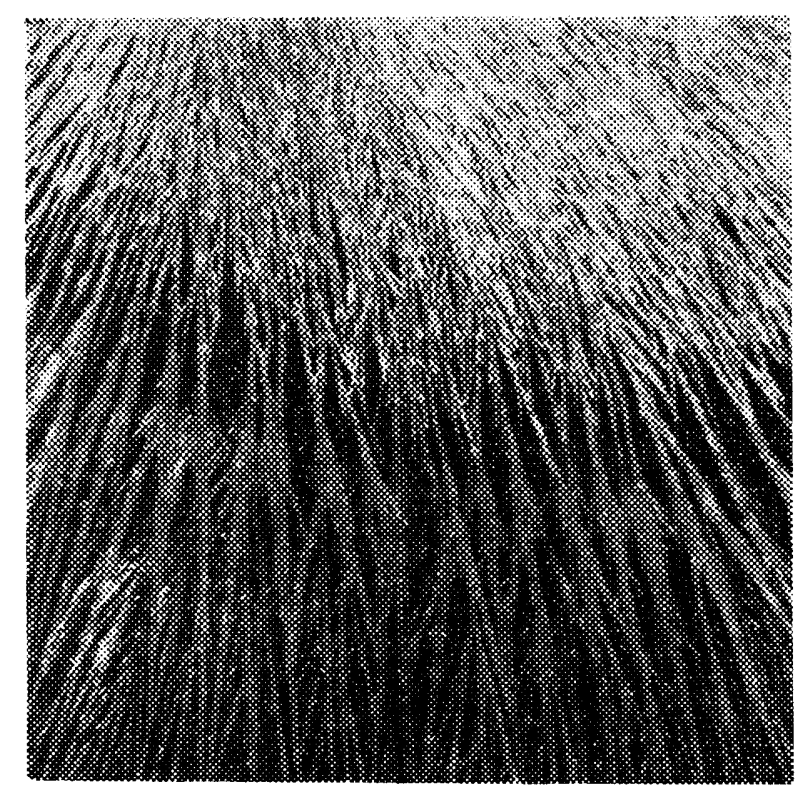

fig. 18

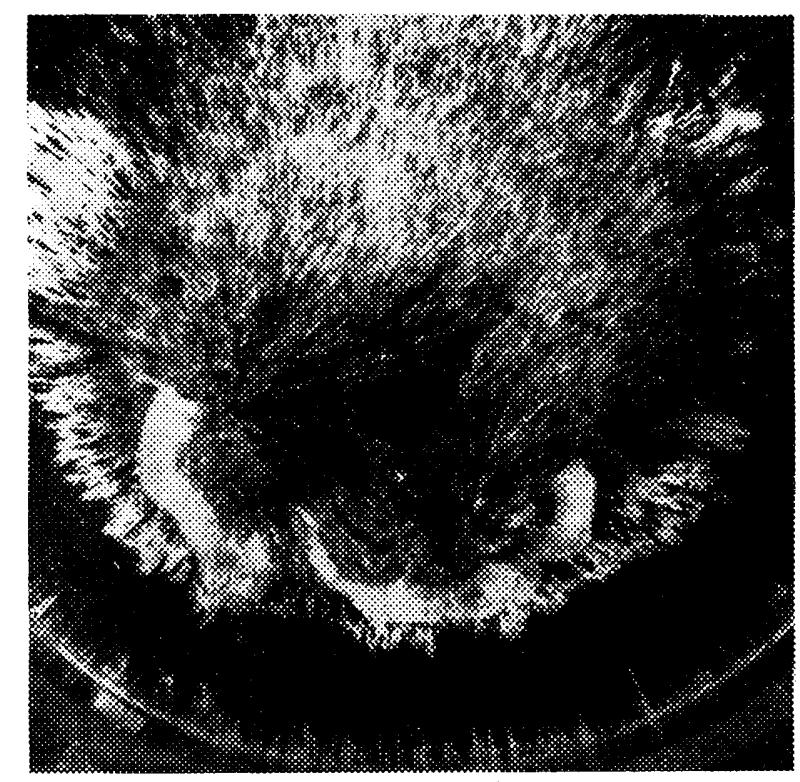

fig. 20

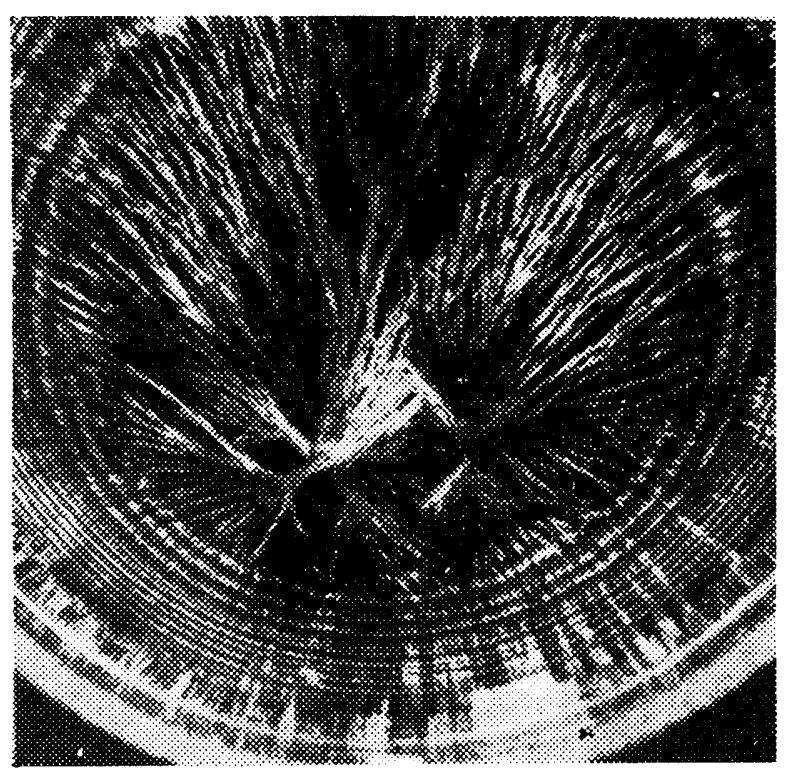

fig• 22

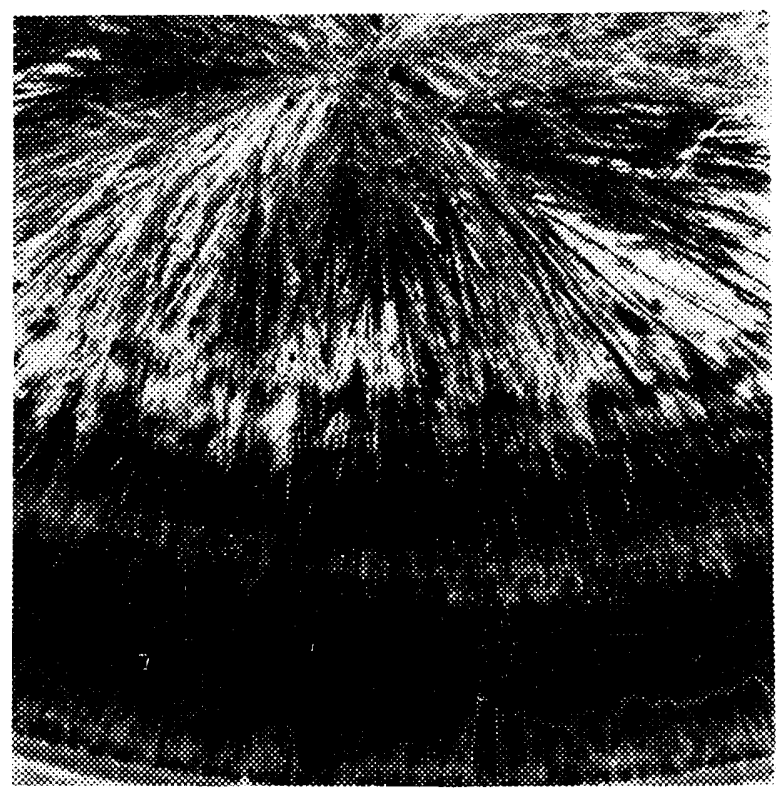

fig. 19

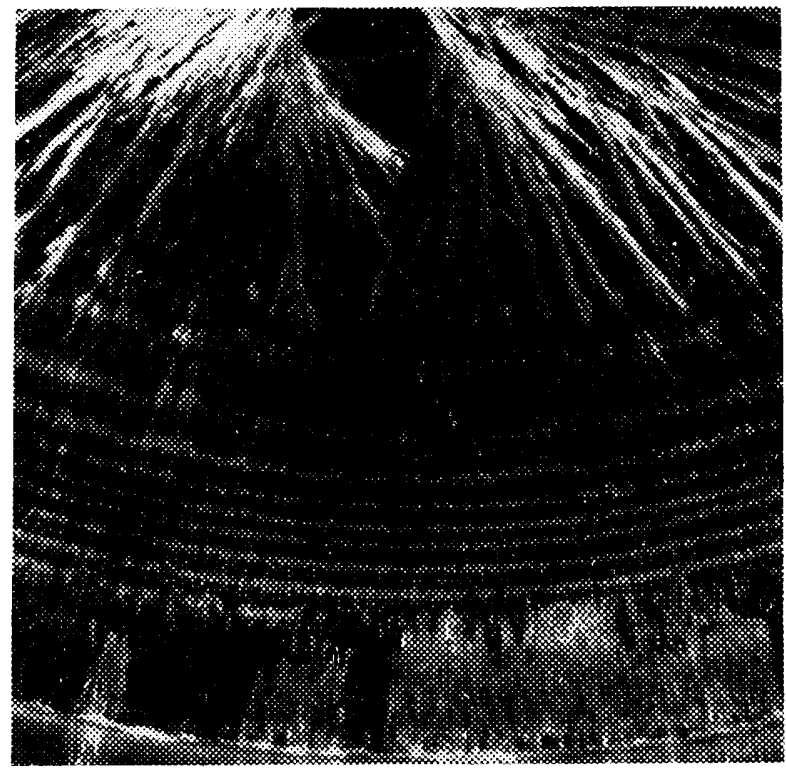

fig. 21

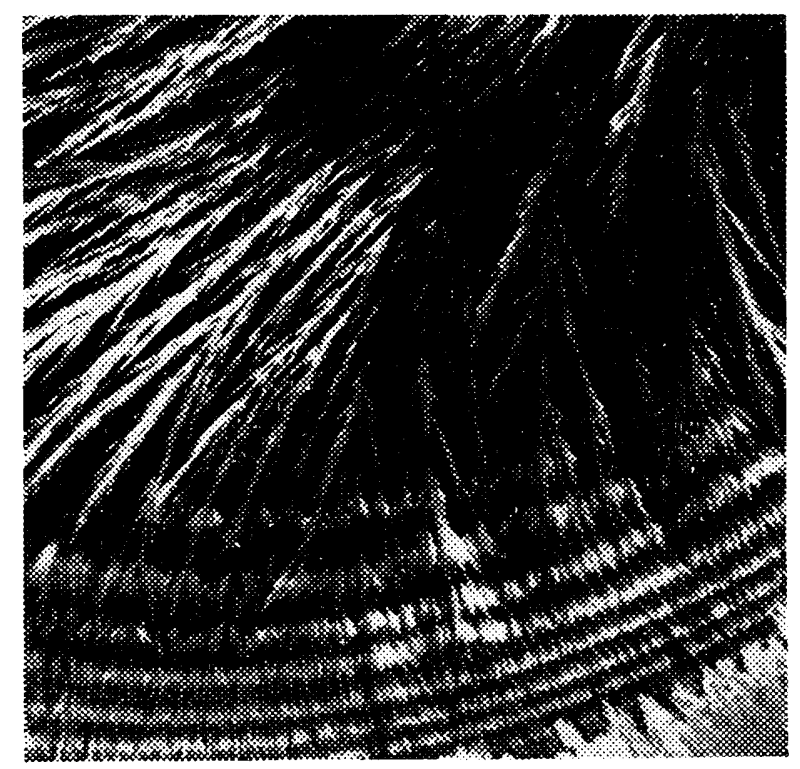

fig. 23 


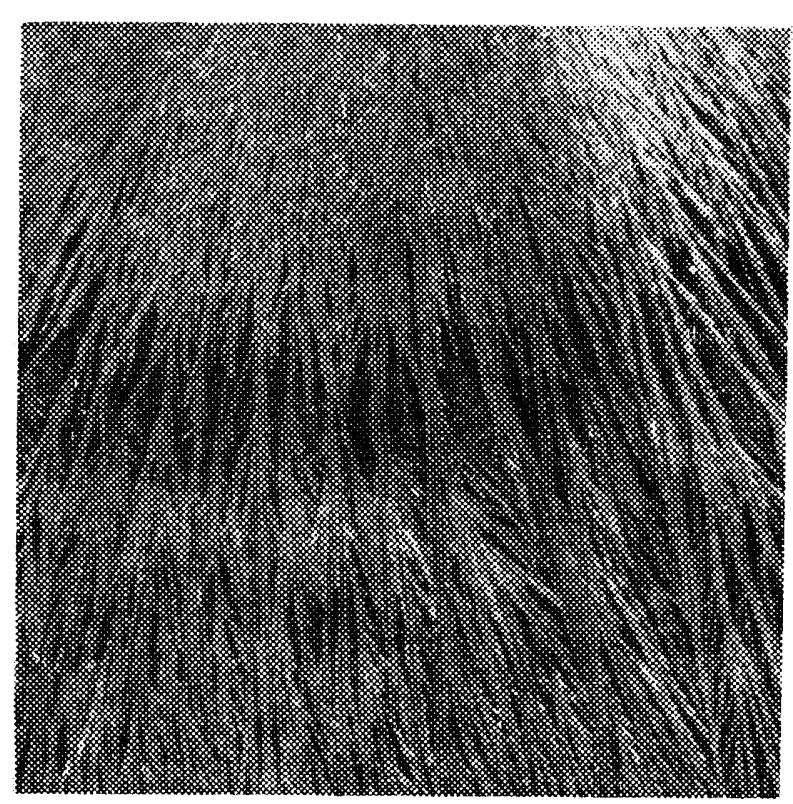

fig. 24

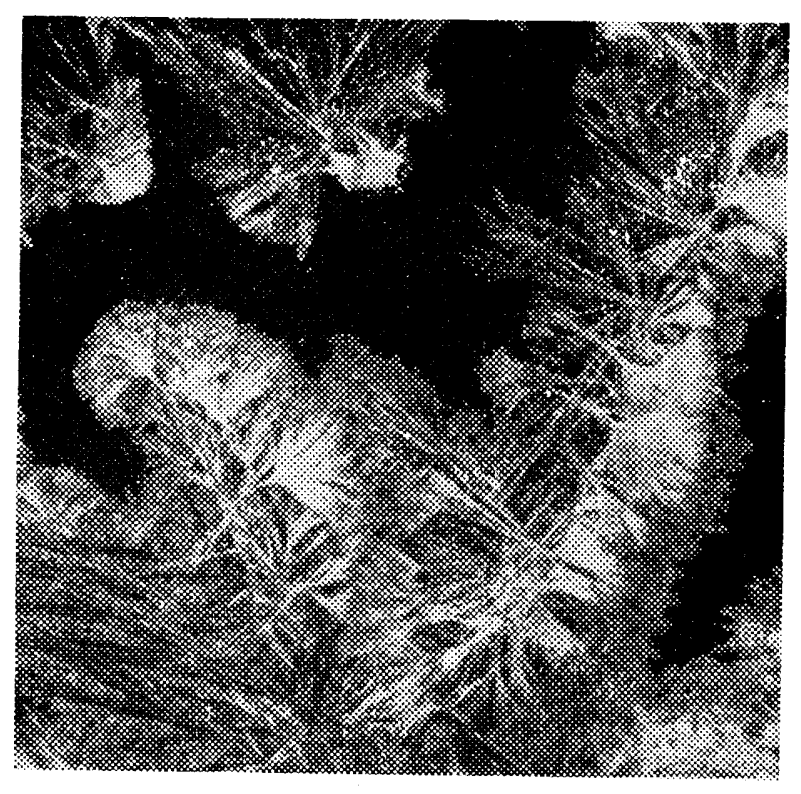

fig. 26

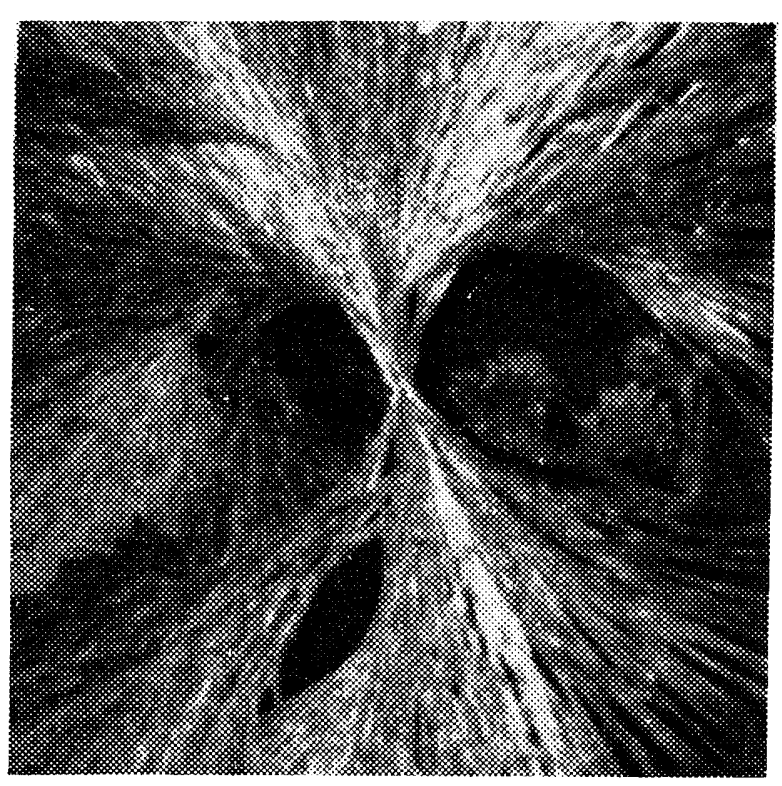

fig. 28

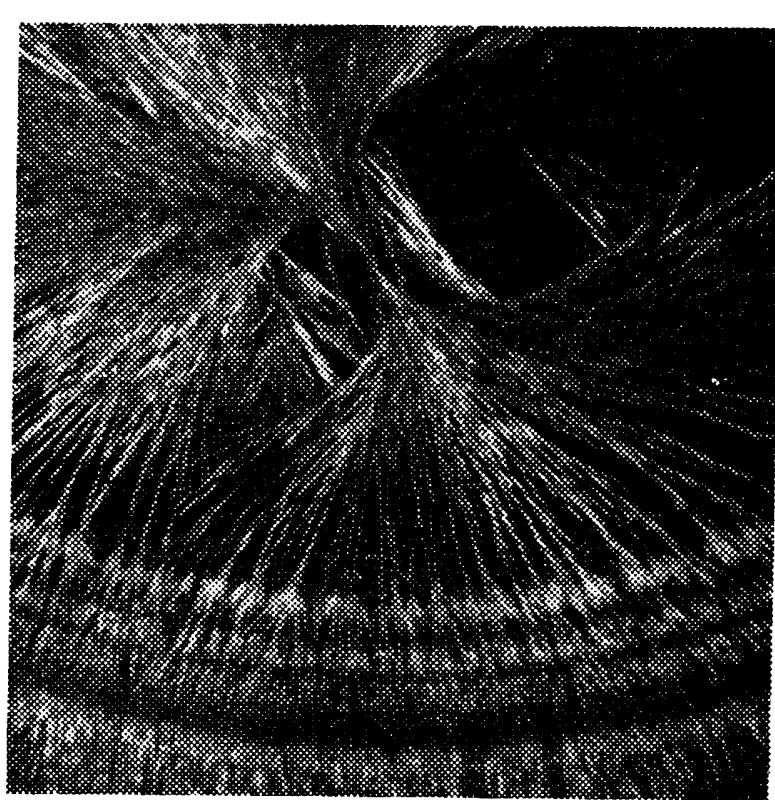

fig. 25

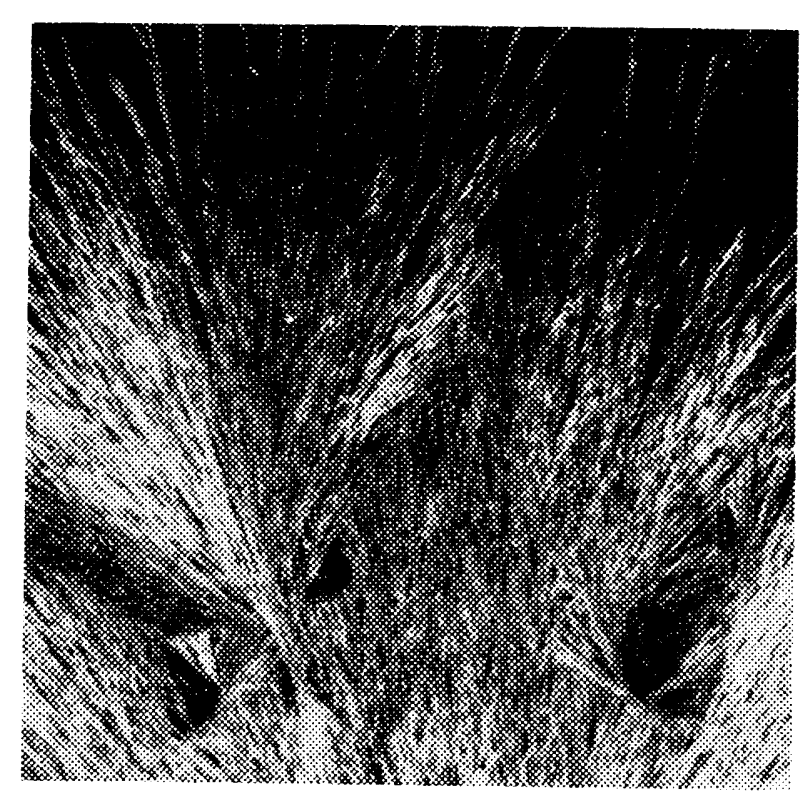

fig. 27

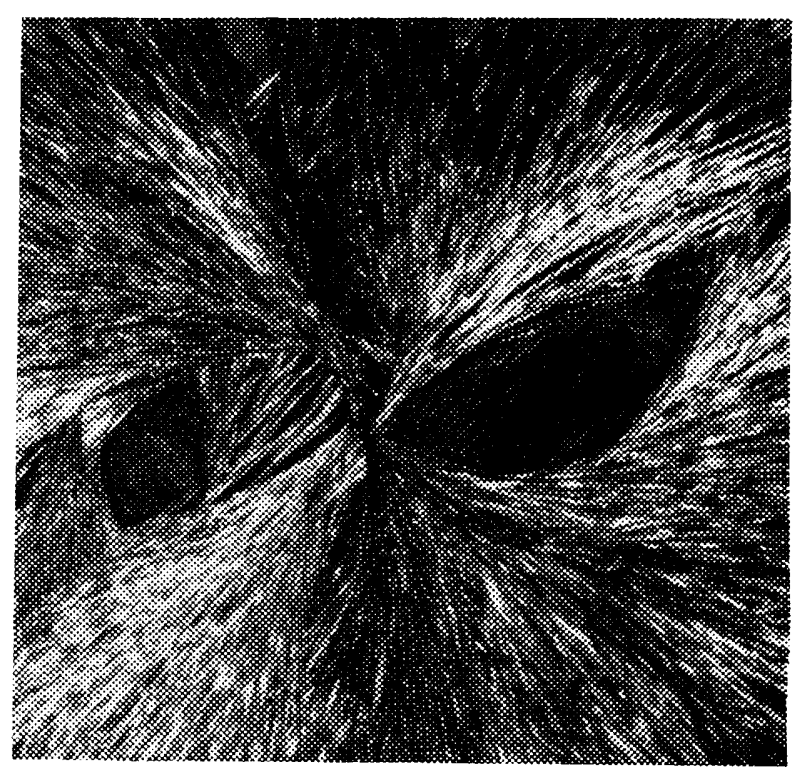

fig. 29 
Anais da E.S.A. "Luiz de Queiroz"

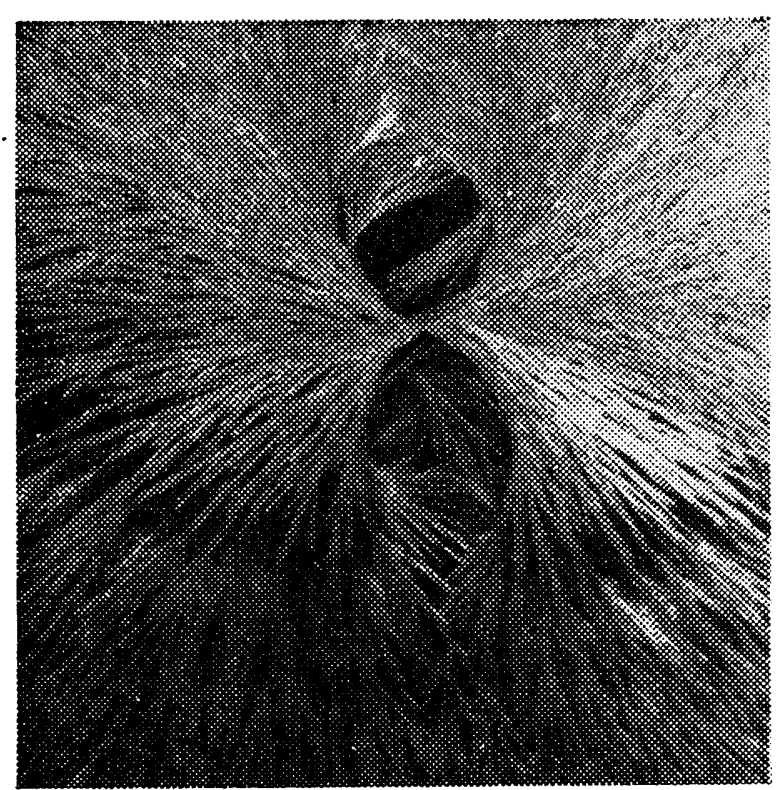

fig. 30

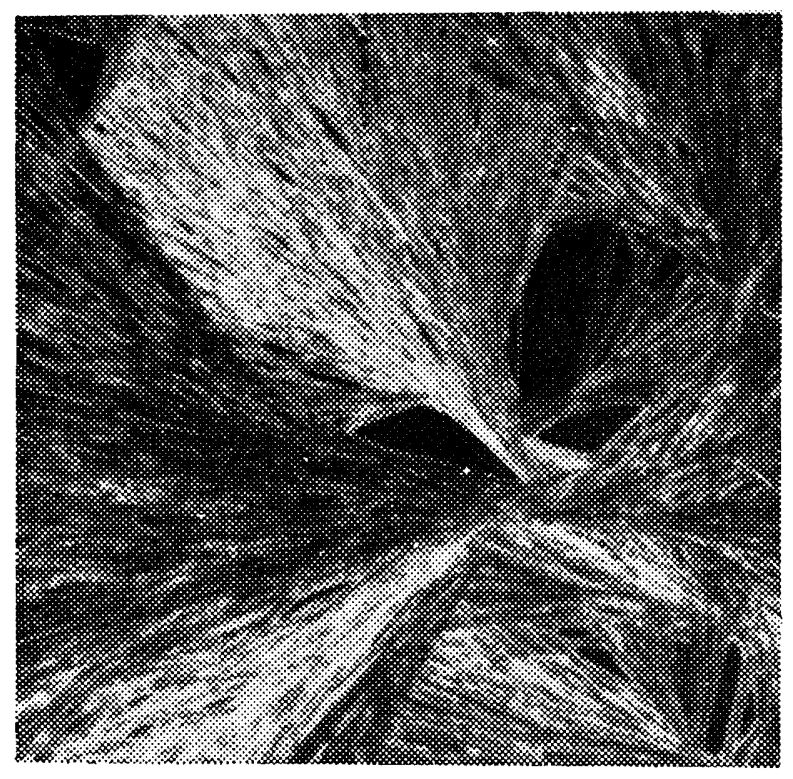

figo 32

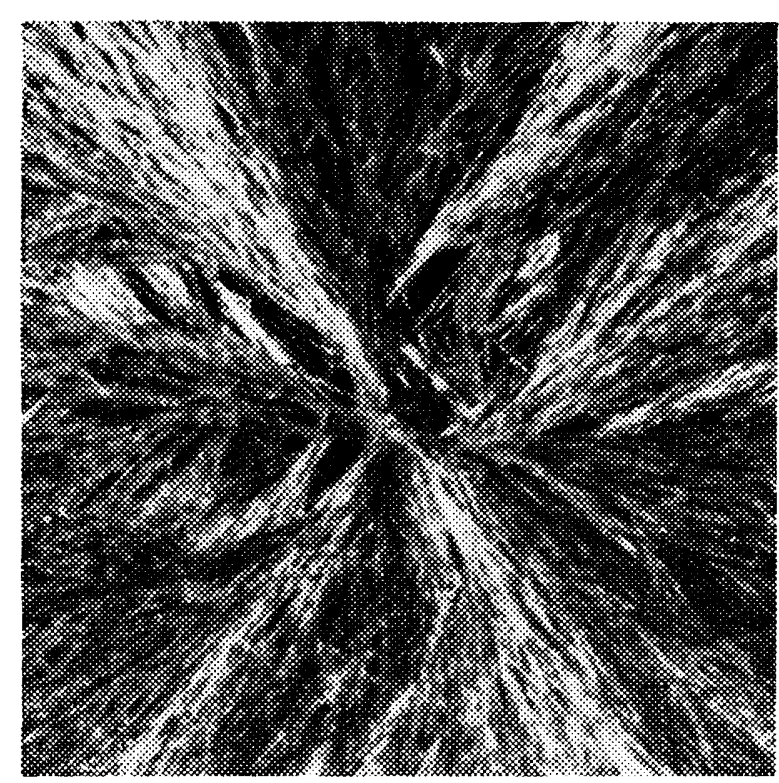

fig. 34

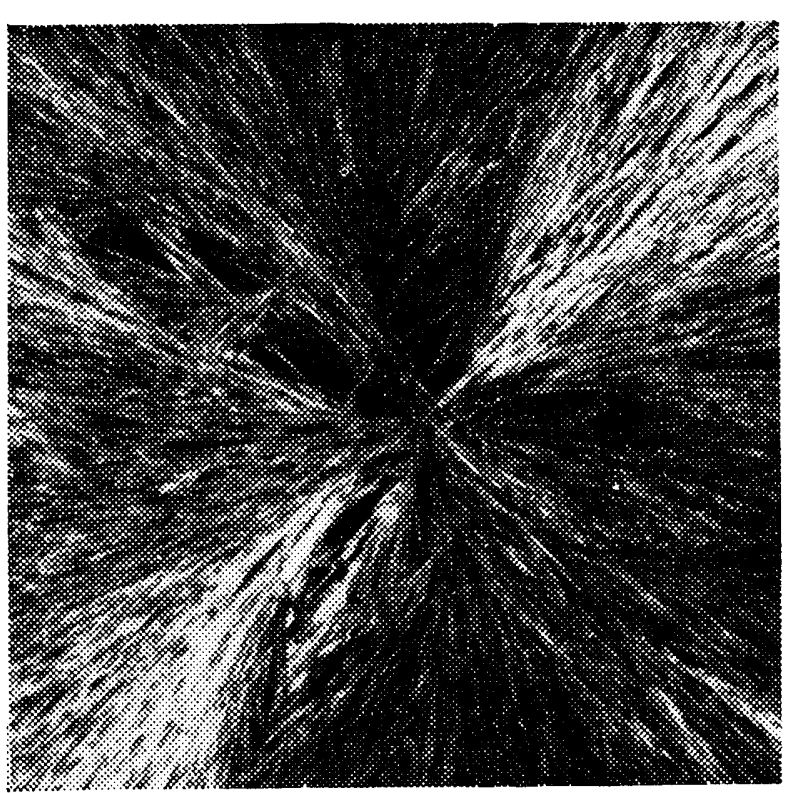

fig• 31

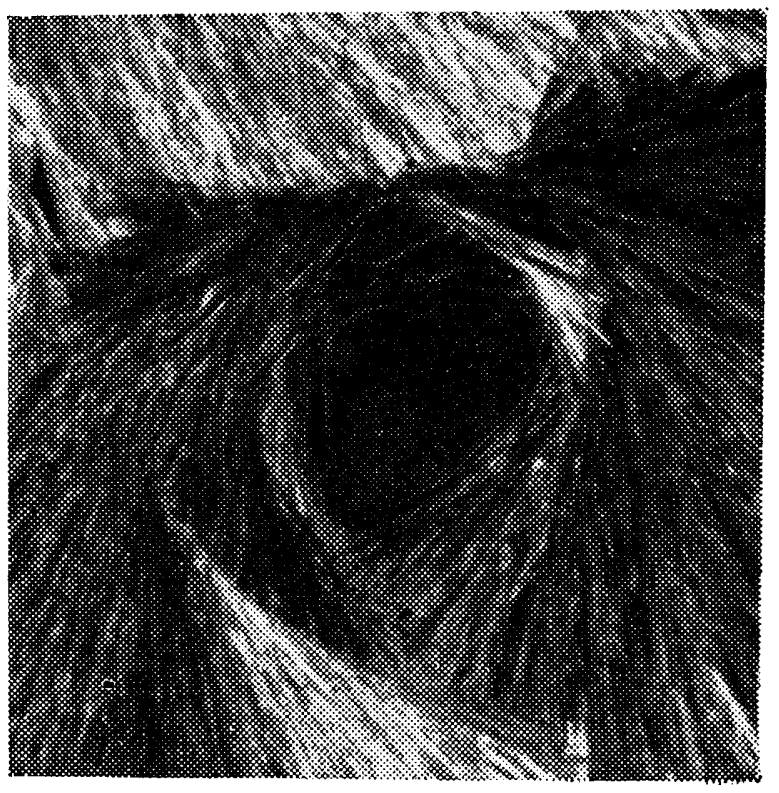

fig. 33 


\section{CONCLUSÕES}

5.1. Os modelos de cristalizacão do cloreto de cobre obtidos a partir de extratos aquosos de feijoeiro exibem grande variedade de caracteres morfológicos. Os modelos de cristalizacão variam em função das concentrações de extrato ou de cloreto de cobre ou da natureza do companheiro de solução (raiz, caule, folha, flor ou semente).

5.2. Além dos caracteres morfológicos já registrados na literatura, o autor considera que outros devem ser introduzidos como termos descritivos, em face de sua frequencia e seu aspecto típico. É o caso de diferenciação geral, bordas vitrificadas, espessamentos, linhas concêntricas e cristalização fibrosa que, para feijoeiro, são frequentemente caracteres diferenciais.

5.3. O exame da morfologia do cloreto de cobre para feijoeiro sugere a necessidade de quantificação dos caracteres morfológicos usados na descrição dos modelos de cristalização, visando a um maior rigor em estudos comparativos.

5.4. Os resultados obtidos indicam que o método de Pfeiffer pode ser aplicado ao feijoeiro para estudar diferenças entre extratos de diferentes orgãos da planta e entre variedades, o que decorre da grande variação observada nos modelos de cristalização.

\section{SUMMARY}

COPPER CHLORIDE MORPHOLOGY IN THE PRESENCE OF ACQUEOUS EXTRACTS OF BEANS (Phaseolus vulgaris L.)

Morphologic features observed in copper chloride crystals formed from the extracted sap of common beans (Phaseolus vulgaris L.) are presented. Various organs namely root, leaf, steam, flower and seed, taken from each of three different varieties were utilized. Some new terms are introduced for the description of the crystals. Identification of varieties and plant organs is made possible by the variation in the morphology of crystallization patterns formed in the presence of liquid extracts from the various organs studied.

\section{LITERATURA CITADA}

ABRAHÃO, I.O. - 1965 - Cristalogênese do cloreto de cobre. Aplicação do método de Pfeiffer ao feijoeiro (Phaseolus vulgaris L.). Tese de doutoramento apresentada à ESALQ, 134pp.

ABRAHÃO, I.O. - 1970 - Aplicação do método de Pfeiffer a sementes de café (Coffea arabica L.). Anais da ESALQ, vol. 27, n. 4, pgs. 61-71.

KRU்GER, H. Tagezeiten-Rhytmen bei Pflanzen. Weleda-Nachrichten 22, 8-11. 1949. 
KRÜGER, H. Kupferchlorid - Kristallisationen, ein Reagens auf Gestaltungskrafte des Lebendigen. Weleda-Schriftenreihe Heft 1, 5-30. 1950.

MORRIS, DANIEL LUZON \& MORRIS, CAROL TILDEN. Specific effects of certain tissue extracts on the crystallization pattern of cupric chloride. Journal of Physical Chemistry 43, 623-629. 1938.

MORRIS, DANIEL LUZON \& MORRIS, CAROL TILDEN. Glycogen in the seed of Zea mays (variety golden bantam). The Journal of Biological Chemistry. Baltimore, U.S.A. Vol. 130, 535-544. 1939.

MORRIS, DANIEL LUZON \& MORRIS, CAROL TILDEN. The modification of cupric chloride crystallisation patterns by traces of proteins. The Journal of Biological Chemistry. Baltimore, U.S.A. Vol. 141, 515-521. 1941.

PFEIFFER, EHRENFRIED. Kristalle. Orient-Occident - Verlag Stuttgart, Alemanha. 1930. 81p.

PFEIFFER, EHRENFRIED. Sensitive Crystallization. Chemical Products and the chemical news. Londres, n. ${ }^{\circ} 3,21-25.1940$.

SELAWRY, A. \& SELAWRY, O. Die Kupferchloridkristallisation in Naturwissenschaft und Medicin. Gustav Fischer - Verlag, Stuttgart, Alemanha. 1957. 232p. 